\title{
Effects of bolus doses of fat on small intestinal structure and on release of gastrin, cholecystokinin, peptide tyrosine-tyrosine, and enteroglucagon
}

\author{
A P Jenkins, M A Ghatei, S R Bloom, R P H Thompson
}

\begin{abstract}
To investigate the enterotrophic effects of bolus doses of long chain triglycerides, two groups of eight female Wistar rats were fed identical diets with $48 \cdot 2 \%$ total calories as the essential fatty acid rich oil Efamol. To one group the oil was given in twice daily bolus doses by gavage, while for the other group the oil was mixed with the remainder of the feed and thus consumed over 24 hours. The animals were killed after 20 to 22 days. Bolus dosing significantly increased parameters of mucosal mass along the length of the small intestine in association with an increase in two hour accumulation of vincristine arrested metaphases in small intestinal crypts. In a second experiment, four replicate studies were carried out, each involving two groups of 12 rats respectively fed as described above. After 21 days one animal from each group was killed every two hours, providing regular plasma samples over 24 hours for measurement of gastrin, cholecystokinin, peptide tyrosinetyrosine and enteroglucagon. Bolus dosing markedly enhanced release of peptide tyrosine-tyrosine and enteroglucagon, but not of gastrin or cholecystokinin. Thus, the enhanced enterotrophic effects of bolus doses of long chain triglycerides could be mediated by release of a distally located gut peptide, perhaps enteroglucagon.
\end{abstract}

The presence of food within the lumen maintains small intestinal structure and function (luminal nutrition).' Luminal nutrients may stimulate mucosal cell proliferation both by a direct action, perhaps related to the "workload of absorption, ${ }^{23}$ and by indirect actions, through release of an enterotrophic peptide ${ }^{4}$ and of pancreaticobiliary secretions, which may themselves have an enterotrophic effect. ${ }^{5}$

Of the individual dietary components, it has been suggested that long chain triglycerides may be especially potent promoters of small intestinal mucosal cell proliferation. ${ }^{6-9}$ Ingested fat also stimulates colorectal mucosal cell proliferation, ${ }^{10}$ and there is evidence that bolus doses exert an even greater effect on the colorectal mucosa than divided doses. "It is, therefore, possible that the trophic effect of long chain triglycerides to the small intestine may also be greater after bolus doses than divided doses.

Two experiments were undertaken. In the first, the trophic effects to the rat small bowel of bolus doses of long chain triglycerides were compared with those of the same daily dose consumed more gradually over 24 hours. The mechanism of the observed changes was investigated in the second experiment by determining the 24 hour profile of release of each of four gut peptides in relation to the method of fat ingestion.

\section{Methods}

ANIMALS AND DIETARY CONSTITUENTS

Both experiments were done on young adult female Wistar rats $(185-220 \mathrm{~g})$. The animals were housed individually in cages with wire bottoms to reduce coprophagia. They were kept to a 12 hour light ( 0700 to 1900 hours): 12 hour dark cycle and were allowed access to tap water ad libitum.

The source of dietary long chain triglycerides was the essential fatty acid rich oil Efamol (Scotia Pharmaceuticals Ltd, Surrey, United Kingdom), the composition of which is shown in Table $\mathrm{I}$. Dietary amino acids were provided by a complete protein hydrolysate (Albumaid Complete, Scientific Hospital Supplies, Liverpool, United Kingdom) and carbohydrate given as dextrose monohydrate (Evans Medical Ltd, Horsham, Sussex, United Kingdom). $2.24 \mathrm{~g}$ of a vitamin/mineral mixture (Special Diets Services Ltd, Essex, United Kingdom) was supplemented for every $100 \mathrm{kcal}$ diet. The diet contained no fibre or other non-absorbable bulk.

\section{EXPERIMENT I}

Two groups of eight rats were fed diets of identical composition, in which Efamol contributed $48 \cdot 2 \%$, glucose $36 \cdot 5 \%$ and amino acids $15.3 \%$ calories. Each rat was given a total of $52.3 \mathrm{kcal} /$ day and thus received $3 \mathrm{ml}(2.8 \mathrm{~g})$ Efamol, $5.3 \mathrm{~g}$ dextrose monohydrate and $2.7 \mathrm{~g}$ Albumaid daily. This daily ration was close to the average intake of rats feeding ad libitum from a diet of similar composition. ${ }^{12}$ To one of the groups of rats the Efamol was administered in twice daily $1.5 \mathrm{ml}$ bolus doses by gavage separately from the remainder of the diet (the 'bolus diet'), while for the other group the Efamol was mixed with the remainder of the feed and therefore consumed over the course of 24

TABLE I Composition of Efamol

\begin{tabular}{lc}
\hline & $\begin{array}{l}\text { Total calories } \\
(\%)\end{array}$ \\
\hline 18:2 Linoleic acid & $75 \cdot 00$ \\
18:3 Gamma linolenic acid & $9 \cdot 00$ \\
16:0 Palmitic acid & $5 \cdot 50$ \\
18:0 Stearic acid & $2 \cdot 00$ \\
18:1 Oleic acid & $8 \cdot 50$ \\
\hline
\end{tabular}

\author{
Bloom \\ Correspondence to: \\ Dr A P Jenkins \\ Gastrointestinal Laboratory, \\ The Rayne Institute, St \\ Thomas' Hospital, London \\ Accepted for publication \\ 28 May 1991
}


hours (the ('mixed diet'). This second group received $1.5 \mathrm{ml}$ tap water twice daily by gavage. The boluses were given at 0900 and 1700 hours. The remainder of the 'bolus diet' (glucose and amino acids) and all of the 'mixed diet' were fed to the animals at 0900 hours in low spillage glass containers. ${ }^{13}$ The experiment was started on a Wednesday and lasted for 20 to 23 days. On the Saturdays and Sundays falling within the period of the study, animals receiving the 'bolus diet' were given only one dose of Efamol by gavage, the remainder being mixed with the rest of the feed.

During the first two days of the study, while habituating to the diets, many rats, and especially those receiving the 'bolus diet', left some of their feed uneaten; this was discarded. Subsequently, most rats in both groups consumed all of their diet on each of the remaining 18 to 21 days. If any rats left diet uneaten, this food was readministered equally among the remaining rats in the same group by adding it to the following day's feed. On a given day, the maximum amount of food ever left by any one rat to be subsequently readministered had an energy content of $10.9 \mathrm{kcal}$, and the maximum amount left over a whole group had an energy content of $15 \cdot 2 \mathrm{kcal}(3 \cdot 6 \%$ of daily calories fed to the group). The readministration of uneaten diet ensured that both groups were closely matched for total energy and fat intake over the course of the study.

After eight days, all faeces were collected for 48 hours and the dry weights measured. The faeces for each group were then pooled and total fat content estimated. ${ }^{1+}$

After 20 days, two rats from each group were killed by overdose of halothane anaesthetic and, after both 21 and 22 days, three rats from each group were similarly killed. Animals were killed

TABLE II Effects of diet on rat weight and intestinal length

\begin{tabular}{llll}
\hline & Mixed diet & Bolus diet & t-Test \\
\hline Rat weight gain $(\mathrm{g})$ & \multicolumn{1}{c}{$12 \cdot 0$} & $9 \cdot 0$ & $\mathrm{NS}$ \\
Final rat weight $(\mathrm{g})$ & $\begin{array}{l}(2 \cdot 5) \\
218 \cdot 5\end{array}$ & $\begin{array}{l}(3 \cdot 6) \\
216 \cdot 6\end{array}$ & $\mathrm{NS}$ \\
Small intestinal & $(4 \cdot 5)$ & $(3 \cdot 4)$ & $\mathrm{NS}$ \\
length $(\mathrm{cm})$ & $110 \cdot 6$ & $110 \cdot 6$ & $\mathrm{~N}$ \\
\hline
\end{tabular}

TABLE III $33 \%$ Small intestinal distance

\begin{tabular}{|c|c|c|c|}
\hline & Mixed diet & Bolus diet & $t$-Test \\
\hline Crypt depth $(\mu \mathrm{m})$ & $\begin{array}{l}155 \cdot 48 \\
(5 \cdot 31)\end{array}$ & $\begin{array}{l}176 \cdot 39 \\
(7 \cdot 04)\end{array}$ & $\mathrm{p}<0.01$ \\
\hline Villus height $(\mu \mathrm{m})$ & $\begin{array}{l}396 \cdot 16 \\
(20 \cdot 10)\end{array}$ & $\begin{array}{l}482 \cdot 75 \\
(22 \cdot 27)\end{array}$ & $\mathrm{p}<0.01$ \\
\hline $\begin{array}{l}\text { Epithelial cell height } \\
(\mu \mathrm{m})\end{array}$ & $\begin{array}{l}26 \cdot 36 \\
(1 \cdot 64)\end{array}$ & $\begin{array}{l}28 \cdot 18 \\
(1 \cdot 14)\end{array}$ & NS \\
\hline $\begin{array}{l}\text { Muscularis propria } \\
\text { thickness }(\mu \mathrm{m})\end{array}$ & $\begin{array}{l}70 \cdot 93 \\
(4 \cdot 80)\end{array}$ & $\begin{array}{l}75 \cdot 84 \\
(4 \cdot 65)\end{array}$ & NS \\
\hline
\end{tabular}

TABLE IV $\quad 100 \%$ Small intestinal distance

\begin{tabular}{|c|c|c|c|}
\hline & Mixed diet & Bolus diet & $t$-Test \\
\hline Crypt depth $(\mu \mathrm{m})$ & $\begin{array}{l}110 \cdot 07 \\
(8 \cdot 09)\end{array}$ & $\begin{array}{l}141 \cdot 50 \\
(7 \cdot 71)\end{array}$ & $\mathrm{p}<0.01$ \\
\hline Villus height $(\mu \mathrm{m})$ & $\begin{array}{l}160 \cdot 39 \\
(15 \cdot 02)\end{array}$ & $\begin{array}{l}228 \cdot 75 \\
(14 \cdot 53)\end{array}$ & $\mathrm{p}<0.01$ \\
\hline $\begin{array}{l}\text { Epithelial cell height } \\
(\mu \mathrm{m})\end{array}$ & $\begin{array}{l}19.81 \\
(0 \cdot 68)\end{array}$ & $\begin{array}{l}22 \cdot 24 \\
(0 \cdot 83)\end{array}$ & $\mathrm{p}<0.05$ \\
\hline $\begin{array}{l}\text { Muscularis propria } \\
\text { thickness }(\mu \mathrm{m})\end{array}$ & $\begin{array}{l}65.60 \\
(8 \cdot 61)\end{array}$ & $\begin{array}{l}82 \cdot 44 \\
(7 \cdot 71)\end{array}$ & NS \\
\hline
\end{tabular}
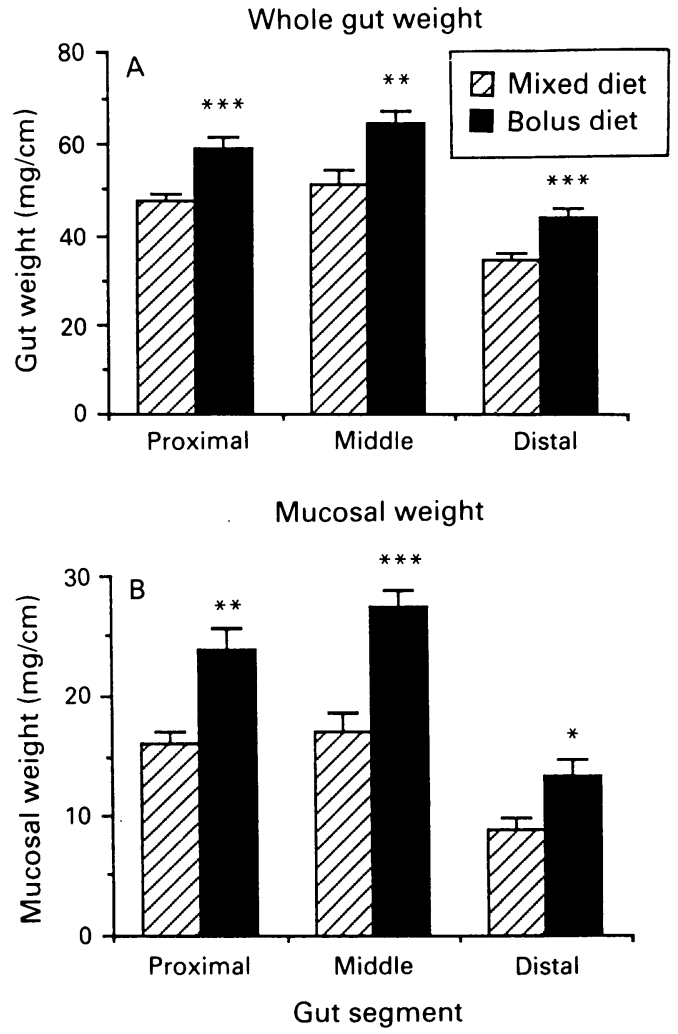

Figure 1: Effect of diet on (a) segment whole gut weight, $(b)$ segment mucosal weight. Significance (bolus $\mathrm{v}$ mixed diet): ${ }^{\star} p<0.05,{ }^{\star \star} p<0.005,{ }^{\star \star} p<0.001$ (t-test).

between 0900 and 1300 hours, exactly two hours after intraperitoneal vincristine sulphate (Lilly France SA, Fegersheim, France; $1 \mathrm{mg} / \mathrm{kg}$ ). All animals of both groups received half their normal intake of diet (including oil) on the day before being killed. Thus, the animals were effectively fasted for some hours before being killed. This was to ensure that there was no lipid in the gut lumen at dissection, because previous experience had shown that intraluminal fat was difficult to flush away.

The small intestine, including part of the duodenum, was removed from the duodenal papilla to the ileocaecal valve. Its length was measured under $10 \mathrm{~g}$ vertical tension and the intestine divided into three equal length segments (proximal, middle, and distal). One $\mathrm{cm}$ samples were taken for subsequent histology from the proximal and distal ends of the proximal segment and distal ends of the middle and distal segments - that is, at distances of $0 \%, 33 \%, 66 \%$ and $100 \%$ along the removed small intestine. The segments of small intestine were flushed with ice cold $0.9 \%$ sodium chloride solution followed by air. Adherent fragments of mesentery were carefully dissected free and the segments weighed to give an estimate of whole gut weight. Subsequently, the segments were slit open longitudinally and the mucosa was gently blotted with tissue paper, scraped off with a glass slide, weighed and frozen at $-20^{\circ} \mathrm{C}$ for later determination of protein and DNA content. ${ }^{1516}$

\section{HISTOLOGICAL MEASUREMENTS}

The $1 \mathrm{~cm}$ samples of small intestine were slit open longitudinally and orientated mucosal 

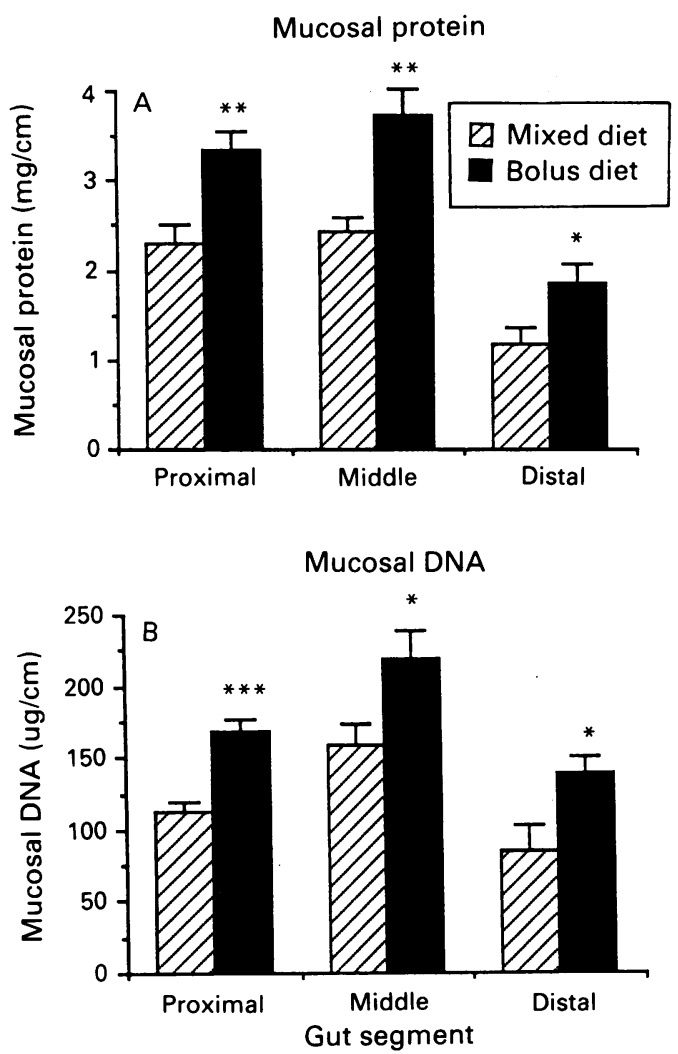

Figure 2: Effect of diet on (a) segment mucosal protein, (b) segment mucosal DNA. Significance (bolus v mixed diet): ${ }^{\star} p<0.05,{ }^{\star} p<0.005, \star \star \star p<0.001$ (t-test).

surface uppermost on small pieces of card. They were fixed in Carnoy's fluid and stored in $70 \%$ aqueous ethanol (v/v). A portion of each sample was bulk stained using the Feulgen reaction, the two hour accumulation of vincristine arrested metaphases counted in 10 randomly selected, microdissected crypts ${ }^{17}$ and the mean calculated.

At distances $33 \%$ and $100 \%$ the remainder of each small intestinal sample was embedded in paraffin and transverse sections were cut at a thickness of $5 \mu \mathrm{m}$ before being stained with haematoxylin-eosin. For each specimen measurements were made of villus vertical height, crypt depth, and epithelial cell height at half villus height. These measurements were made only in villi and crypts cut parallel to their longitudinal axes and the mean of ten determinations derived. The combined thickness of the circular and longitudinal muscle layers (muscularis propria) was also measured.

\section{EXPERIMENT 2}

Two groups of 12 rats were respectively fed the Efamol rich 'bolus diet' and 'mixed diet', as described for experiment 1 . After 21 days, one animal from each group was killed by cardiac puncture and exsanguination under ether anaesthesia every two hours starting at 0800 hours. The blood from each rat was immediately transferred to a $10 \mathrm{ml}$ lithium heparin tube containing $200 \mu \mathrm{l}$ aprotinin (Trasylol; Bayer UK Ltd, Berkshire, United Kingdom), centrifuged at $400 \mathrm{~g}$ for 10 minutes and the plasma frozen at $-20^{\circ} \mathrm{C}$. Thus, samples were obtained at regular intervals over the course of 24 hours. As the animals received their normal allocation of feed on the final day, an estimate of the diurnal profile of plasma levels of gut peptides in relation to diet could, therefore, be made.

Plasma levels of gastrin, ${ }^{18}$ peptide tyrosinetyrosine, ${ }^{19}$ enteroglucagon ${ }^{20}$ and cholecystokinin $^{21}$ were measured by radioimmunoassay. Enteroglucagon was determined by subtracting specifically measured pancreatic glucagon from total N-terminal glucagon immunoreactivity, and cholecystokinin derived by subtracting the results of a gastrin specific assay from the total cholecystokinin.

The amount of food consumed by each animal on the final day by the time it was killed was also measured in order to show the diurnal pattern of intake of each diet. For the 'bolus diet', therefore, the measurements included the intake both of the bolus doses of oil and of the separately administered glucose and amino acids.

The whole experiment was repeated a further three times, so that there were four measurements at each time point (except for cholecystokinin, where $\mathrm{n}=$ three).

\section{STATISTICAL ANALYSIS}

In experiment 1 the groups were compared using Student's unpaired $t$ test.

In experiment 2 the areas under the curves relating plasma gut peptide levels to time were compared using Wilcoxon's two-sample test, as sample size was too small to determine whether there was a normal distribution.

Results are expressed as means (SEM), unless otherwise indicated.

\section{Results}

\section{EXPERIMENT I}

There was no significant difference between the two groups in weight gain or in final body weight (Table II). Small intestinal length also did not differ significantly between the groups (Table II).

Whole gut weight, mucosal weight and mucosal protein and DNA were significantly increased by bolus dosing with Efamol compared with the 'mixed diet' in all three small intestinal segments (Figs 1, 2).

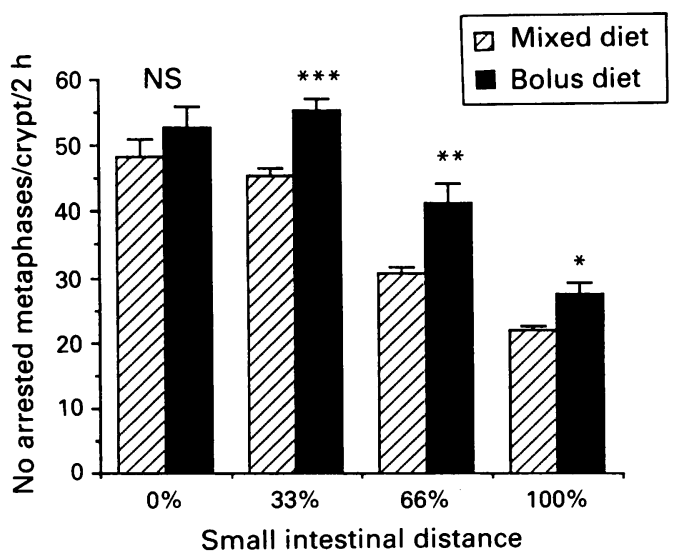

Figure 3: Effect of diet on two hour metaphase accumulation. Significance (bolus $\mathrm{v}$ mixed diet): ${ }^{\star} p<0.05$, ${ }_{\star \star} p<0.005, \star \star \star p<0.001$ (t-test). 


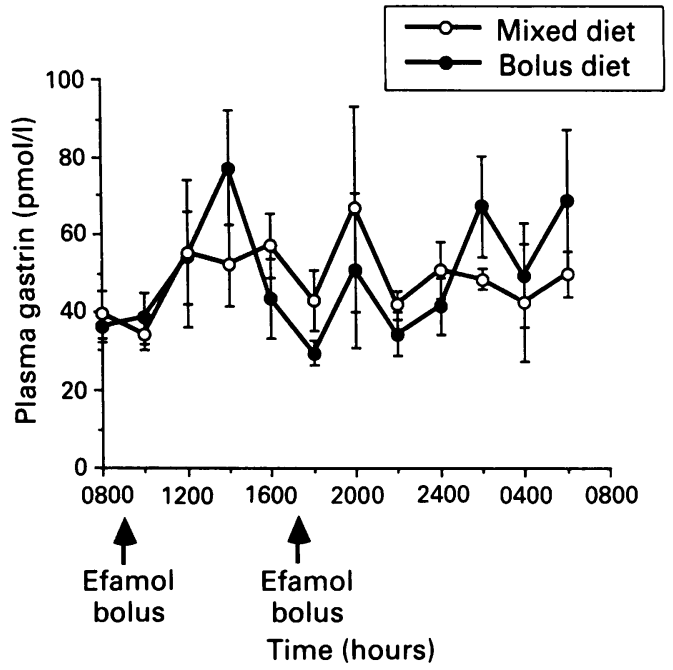

Area under the curve (pmol.h/l)

Mixed diet $1072(81)$, NS (Wilcoxon's Bolus diet $1076(115)$ test)

Figure 4: Diurnal profile of plasma levels of gastrin in relation to diet. Each point is the mean (SEM) of four measurements.

Bolus dosing also significantly increased two hour metaphase accumulation at all points along the small intestine apart from $0 \%$, although the same trend was also present at this distance (Fig 3).

Morphometric parameters for small intestinal distances of $33 \%$ and $100 \%$ are shown in Tables III and IV respectively. At both points bolus dosing increased crypt depth and villus height. Epithelial cell height was significantly increased by the 'bolus diet' at $100 \%$, but not at $33 \%$, although the same trend was present. Muscularis propria thickness was not signifcantly different between the two groups, although the trend was in favour of the group receiving bolus doses of Efamol.

There was a small but non-significant difference between the two groups in the dry

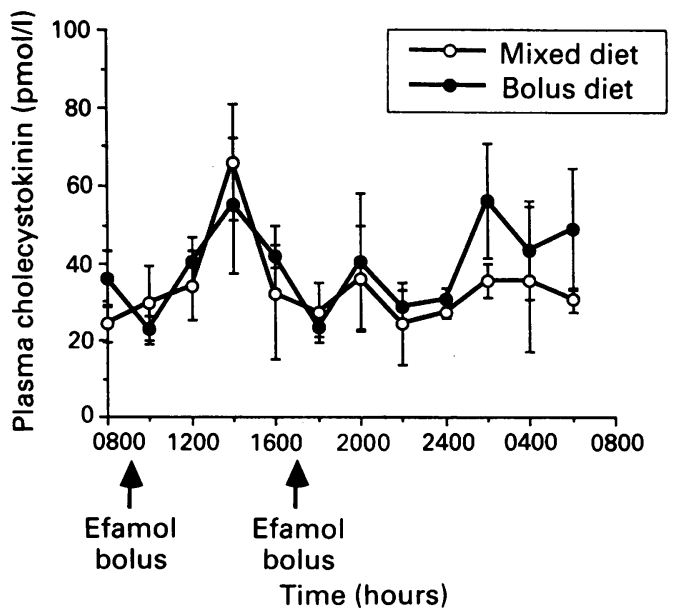

Area under the curve (pmol.h/l)

$\left.\begin{array}{ll}\text { Mixed diet } & 753(35) \\ \text { Bolus diet } & 850(75)\end{array}\right\} \begin{aligned} & \text { NS (Wilcoxon's } \\ & \text { test) }\end{aligned}$

Figure 5: Diurnal profile of plasma levels of cholecystokinin in relation to diet. Each point is the mean (SEM) of three measurements. weights of the faeces collected for 48 hours between days 8 and 10 of the study ('mixed diet': $1.72(0 \cdot 19) \mathrm{g} /$ rat $v$ 'bolus diet': $1.43(0.21) \mathrm{g} /$ rat). The total fat content of the pooled faeces for the 'mixed diet' was $5 \cdot 1 \mathrm{mmol}$ and for the 'bolus diet' $3.8 \mathrm{mmol}$.

\section{EXPERIMENT 2}

The curves relating plasma levels of gastrin and cholecystokinin to time are shown in Figures 4 and 5. Bolus dosing did not affect plasma levels of either peptide and there were no significant differences between the areas under the respective curves for the two diets.

On the other hand, bolus dosing with Efamol markedly enhanced release of peptide tyrosinetyrosine and enteroglucagon (Figs 6 and 7). For both peptides the areas under the curves for the 'bolus diet' were significantly greater than those for the 'mixed diet'.

Not surprisingly, the energy intake of animals receiving the 'bolus diet' tended to be greater than the intake of animals receiving the 'mixed diet' between 0900 and 2000 hours (Fig 8), as the former group had received almost $50 \%$ total calories as bolus doses of oil during this period. After 1800 hours the intake of the group receiving the 'mixed diet' showed a marked increase and by 2200 hours the cumulative intakes for the two high fat diets were the same.

\section{Discussion}

Earlier studies have suggested that the pattern of food intake can itself affect small intestinal mucosal growth. Thus, in intermittently starved rats receiving a mixed diet for 26 weeks small intestinal weight is increased compared with normally fed animals, despite a lower calorie intake, ${ }^{22}$ while in rats starved for four days and refed a pelleted laboratory diet for 88 hours there is an increased crypt cell production rate compared with normally fed rats, despite the fact that food intake on a daily basis is not raised in the

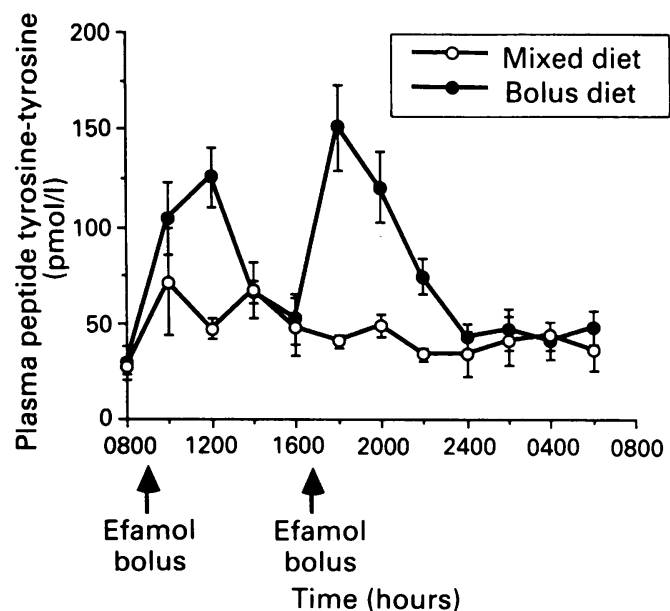

Area under the curve (pmol.h/l)

$$
\left.\begin{array}{ll}
\text { Mixed diet } & 1014(86) \\
\text { Bolus diet } & 1728(75)
\end{array}\right\} \begin{aligned}
& p<0.05 \\
& \text { (Wilcoxon's test) }
\end{aligned}
$$

Figure 6: Diurnal profile of plasma levels of peptide tyrosinetyrosine in relation to diet. Each point is the mean (SEM) of four measurements. 


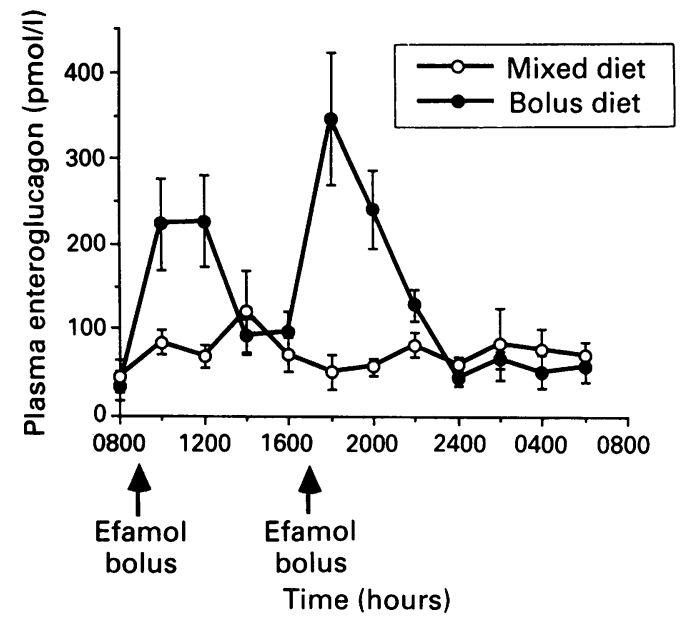

Area under the curve (pmol.h/l)

Mixed diet $1618(182), p<0.05$

Bolus diet $3211(155)\}^{2}$ (Wilcoxon's test)

Figure 7: Diurnal profile of plasma levels of enteroglucagon in relation to diet. Each point is the mean (SEM) of four measurements.

refed animals. ${ }^{23}$ These results suggest that gorging may promote small intestinal hyperplasia in comparison with more gradual ingestion of food. Although starvation produces mucosal atrophy, ${ }^{24}$ it is conceivable that it may also enhance the sensitivity of the mucosal proliferative response to luminal nutrients on subsequent refeeding. ${ }^{25}$

In the current study the animals were not starved and both groups had the same energy intake. The observed changes were thus clearly related to differences in how the oil was administered. But although the animals in the current experiment were given a daily allocation of food close to their ad libitum intake for a similar defined diet, ${ }^{12}$ this daily intake was rather less than that of animals fed laboratory chow ad libitum, ${ }^{26}$ perhaps reflecting the relative palatabilities of the diets. It remains possible, therefore, that the sensitivity of the mucosal

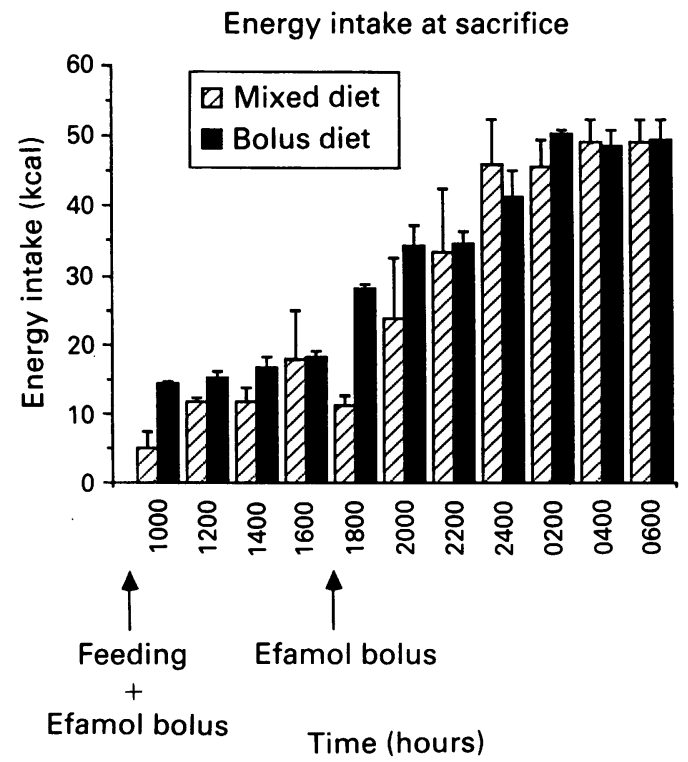

Figure 8: Diurnal pattern of intake of each diet. Each point is the mean $(S E M)$ of four measurements. proliferative response to the Efamol boluses was enhanced by the relatively low energy intake of the animals in the current experiment.

The 'bolus diet' differed from the 'mixed diet' not only in the oil being given in large doses over short time periods, but also in the oil being given separately from the remainder of the feed. It is hard to see, however, how the latter feature could have affected the mucosal response, especially as oil in the 'mixed diet' would have tended to separate from the remainder of the feed in the stomach. ${ }^{27}$ It seems more likely, therefore, that bolus dosing per se was the important factor.

The trophic effects of bolus dosing with Efamol were probably not limited just to the mucosa, as there was also a trend for increased thickness of the muscularis propria after the 'bolus diet'. Moreover, within the mucosa itself bolus dosing not only increased epithelial cell number, but also increased cell size.

As there is convincing evidence that an enterotrophic peptide may be involved in mediating small intestinal adaptive responses, ${ }^{2829}$ in the second experiment the effect of diet on release of gut peptides was investigated. It would have been difficult to interpret nonfasting plasma gut peptide levels taken at a single time point, as the two groups would not have been matched for their respective dietary intakes in the period immediately before sampling. Therefore, a profile of plasma hormone levels over a complete 24 hours was obtained, because during this period the two groups received equal amounts of their respective diets.

Bolus dosing markedly enhanced release of peptide tyrosine-tyrosine and enteroglucagon, but not gastrin or cholecystokinin. The response to bolus dosing, therefore, was selective and not general to all gut peptides, nor even to those peptides that are released specifically by dietary fat, as luminal lipid is a specific stimulus to release of cholecystokinin,,$^{30}$ as well as of peptide tyrosine-tyrosine and enteroglucagon. ${ }^{19} 31$

The enhanced response of cells secreting peptide tyrosine-tyrosine and enteroglucagon may be largely the result of their anatomical location. These cells are found mainly in the distal small bowel and colon. ${ }^{19} 32$ The total amount of lipid reaching a given point in the ileum and the total area of ileum exposed to fat might have been greater after the 'bolus diet' than after the 'mixed diet' as a result of saturation of more proximal absorptive capacity. ${ }^{33}$ Although the faecal fat recoveries in experiment 1 suggest that bolus dosing did not increase, and possibly even decreased, the amount of fat reaching the colon, it is possible that fat in bolus doses travelled further along the small bowel before then being absorbed.

The major site of release of the peptide(s) involved in mediating small intestinal adaptive responses appears to be the distal small bowel and colon, rather than the proximal small bowel. ${ }^{28}$ Therefore, the effects of bolus doses of Efamol on release of peptide tyrosine-tyrosine and enteroglucagon suggest that the increased enterotrophic effects of bolus dosing could be hormonally mediated. Direct infusion studies show that peptide tyrosine-tyrosine has no enterotrophic effect, ${ }^{3+}$ but there is considerable 
circumstantial evidence that enteroglucagon itself may be an enterotrophic peptide. ${ }^{432}$ Nevertheless, recent studies challenge this proposal ${ }^{35-38}$ and, until enteroglucagon can be synthesised in sufficient quantity to test by direct in vivo infusion, its precise role remains uncertain. Therefore, although suggestive, the present findings do not prove that the additional enterotrophic effects of bolus doses of long chain triglycerides are hormonally mediated.

The measures of food intake suggest that, as intended, the intake of Efamol in the 'mixed diet' occurred more gradually over the course of 24 hours than the intake of the bolus doses. Nevertheless, over $50 \%$ ' $r$ the total dose of oil was consumed during six hours between 1800 and 2400 hours in the 'mixed diet' (Fig 8). This was not accompanied by any obvious rise in enteroglucagon or peptide tyrosine-tyrosine (Figs 6 and 7) and so presumably there is a threshold rate, somewhere between the rate of consumption as part of the 'mixed diet' during this evening time period and the rate of bolus administration, at which fat must be ingested to raise the levels of these peptides.

It has been suggested that high fat diets may be useful in enhancing the small intestinal adaptive response in patients after partial small intestinal resection. ${ }^{68}$ The results of the current study suggest that the magnitude of the enterotrophic effect of a high fat diet may be influenced by how that diet is administered. APJ was supported by a Nutritional Research Foundation/British Digestive Foundation Fellowship. We are grateful to Mr N Curtisstaff of the Animal House for giving the intragastric doses, and to the Special Trustees of St Thomas' Hospital for their continuing support. Efamol was a gift from Scotia Pharmaceuticals Ltd and Albumaid a gift from Scientific Hospital Supplies.

1 Dowling RH. Small bowel adaptation and its regulation. Scand f Gastroenterol 1982; 17 (suppl 74): 53-74.

2 Clarke RM. 'Luminal nutrition' versus 'functional workload' as controllers of mucosal morphology and epithelial replacement in the rat small intestine. Digestion 1977; 15. replacemer

3 Richter GC, Levine GM, Shiau Y-F. Effects of luminal glucose versus non-nutritive infusates on jejunal mass and absorption in the rat. Gastroenterology 1983; 85: 1105-12.

4 Bloom SR. Gut hormones in adaptation. Gut 1987; 28 (suppl): 31-5

5 Altman GG. Influence of bile and pancreatic secretions on the size of the intestinal villi in the rat. Am F Anat 1971; 132: 167-77.

6 Morin CL, Grey VL, Garofalo C. Influence of lipids on intestinal adaptation after resection. In: Robinson JWL, Dowling RH, Riecken EO, eds. Mechanisms of intestinal adaptation. Lancaster: MTP Press Ltd, 1982: 175-84.

7 Weinberg LM, Pusateri JP, Levine GM. Comparison of different caloric substrates on intestinal adaptation in the different caloric substrates on intestin

8 Maxton DG, Cynk EU, Jenkins AP, Thompson RPH. Effect of dietary fat on the small intestinal mucosa. Gut 1989; 30 . $1252-5$.

9 Jenkins AP, Thompson RPH. Trophic effect of Efamol on the rat small-intestinal mucosa. Clin Sci 1989; 77: 555-9.

10 Bird RP, Stamp D. Effect of a high fat diet on the proliferative indices of murine colonic epithelium. Cancer Lett 1986; 31 61-7.

11 Stadler J, Stern HS, Sing Yeung K, McGuire V, Furrer R, Marcon N, et al. Effect of high fat consumption on cell proliferation of colorectal mucosa and on soluble faecal bile acids. Gut 1988; 29: 1326-31.

12 Jenkins AP, Thompson RPH. The effect of dietary fat on the distribution of mucosal mass and cell proliferation along the distribution of mucosal mass and cell

13 Senapati A, Johnson C, Brown IMH, Thompson RPH. A method to reduce spillage in pair-fed rats. Anim Technol $1984 ; 35: 123-4$

14 Van de Kamer JH, Ten Bokkel Huinink H, Weyers HA Rapid method for determination of fat in feces. 7 Biol Chem $1949 ; 177 ; 347-55$.

15 Lowry OH, Rosebrough NJ, Farr AL, Randall RS. Protein measurement with the Folin-phenol reagent. F Biol Chem 1951; 193: 265-75.

16 Prasad AS, Du Mouchelle E, Koniuch D, Oberleas D. A simple fluorometric method for the determination of RNA and DNA in tissues. F L ab Clin Med 1972; 80: 598-602.

17 Goodlad RA, Wright NA. Quantitative studies on epithelia replacement in the gut. In: Titchen TA, ed. Techniques in the life sciences. Techniques in digestive physiology. Vol P2. Shannon, Ireland: Elseveir Biomedical Press, 1982: 212/123.

18 Bryant MG, Adrian TE. Gastrin. In: Bloom SR, Long RG, eds. Radioimmunoassay of

19 Adrian TE, Ferri GL. Bacarese-Hamilton AJ, Fuessl HS Polak JM, Bloom SR. Human distribution and release of putative new gut hormone, peptide YY. Gastroenterology putative new gut

20 Ghatei MA, Uttenthal LO, Christofides ND, Bryant MG Bloom SR. Molecular forms of human enteroglucagon in tissue and plasma. Plasma responses to nutrient stimuli in health and in disorders of the upper gastrointestinal tract. $\mathcal{F}$ Clin Endocrinol Metab 1983; 57: 488-95.

21 Adrian TE, Bacarese-Hamilton AJ. Cholecystokinin. In: Bloom SR, Long RG, eds. Radioimmunoassay of gut regulatory peptides. London: WB Saunders, 1982: 60-5.

22 Fabry P, Kujalova V. Enhanced growth of the small intestine in rats as a result of adaptation to intermittent starvation. Acta Anat (Basel) 1960;43: 264-71.

23 Goodlad RA, Al-Mukhtar MYT, Ghatei MA, Bloom SR Wright NA. Cell proliferation, plasma enteroglucagon and Wright NA. Cell proliferation, plasma enteroglucagon and [B] 1983; 43: 55-62.

24 Steiner M, Bourges HR, Freedman LS, Gray SJ. Effect of starvation on the tissue composition of the small intestine in the rat. Am f Physiol 1986; 215: 75-7.

25 Taylor B, Murphy GM, Dowling RH. Pituitary hormones and the small bowel: effect of hypophysectomy on intestinal adaptation to small bowel resection in the rat. Eur $\mathcal{f}$ Clin Invest 1979; 9: 115-27.

26 Young EA, Cioletti LA, Winborn WB, Traylor JB, Weser E. Comparative study of nutritional adaptation to defined formula diets in rats. Am 7 Clin Nutr 1980; 33: 2106-18.

27 Johansson C, Lagerlof HO, Ekelund K, Kulsdom N, Larsson I, Nylind B. Studies of gastrointestinal interactions. III Determinations of gastric secretion and evacuation, biliary and pancreatic secretion, intestinal absorption, intestinal transit time and flow of water in man. Scand $\mathcal{F}$ Gastroentero 1972; 7: 489-99.

28 Appleton GVN, Bristol JB, Williamson RCN. Proximal enterectomy provides a stronger systemic stimulus to intestinal adaptation than distal enterectomy. Gut 1987; 28 (suppl): $165-8$

29 Williamson RCN, Buchholtz TW, Malt RA. Humora stimulation of cell proliferation in small bowel after transection and resection in rats. Gastroenterology 1978; 75: 249-54.

30 Douglas BR, Wouterson RA, Jansen JBMJ, de Jong AJL, Lamers CBHW. The influence of different nutrients on plasma cholecystokinin levels in the rat. Experientia 1988; 44: 21-3.

31 Ohneda A, Yanbe A, Maruhama Y, Ishii S, Kai Y, Abe R, $e$ al. Characterization of circulating immunoreactive glucagon in response to intraduodenal administration of fat in dogs. Gastroenterology 1975; 68: 715-21.

32 Bloom SR, Polak JM. Enteroglucagon and the gut hormone profile of intestinal adaptation. In: Robinson JWL, Dowling RH, Riecken EO, eds. Mechanisms of intestinal adaptation. Lancaster: MTP Press Ltd, 1982; 189-98.

33 Booth CC, Read AE, Jones E. Studies on the site of fat absorption. 1. The sites of absorption of increasing doses of 131I-labelled triolein in the rat. Gut 1961; 2: 23-31.

34 Savage AP, Gornacz GE, Adrian TE, Ghatei MA, Goodlad $\mathrm{RA}$, Wright NA, et al. Is raised plasma peptide YY after intestinal resection in the rat responsible for the trophic intestinal resection in the rat resp

35 Gregor M, Menge H, Stossel R, Riecken EO. Effect of monoclonal antibodies to enteroglucagon on ileal adaptation after proximal small bowel resection. Gut 1987; 28 (suppl): 9-14.

36 Gregor M, Stallmach A, Riecken EO. Enteroglucagon does not stimulate proliferation in intestinal epithelial monocultures. Gastroenterology 1989; 96: A183.

37 Johnson IT, Gee JM, Brown JC. Plasma enteroglucagon and small bowel cytokinetics in rats fed soluble non-starch polysaccharides. An F Clin Nutr 1988; 47: 1004-9.

38 Goodlad RA, Ratcliffe B, Fordham JP, Ghatei MA, Domin J, Bloom SR, et al. Plasma enteroglucagon, gastrin and peptide YY in conventional and germ free rats refed with a fibre-free or fibre-supplemented diet. $Q \mathcal{F}$ Exp Physiol 1989; 74: 43742 . 